\title{
Biometrical analysis and selection of tetraploid progenies of Panicum maximum using mixed model methods
}

\author{
Rosangela Maria Simeão Resende( ${ }^{(1)}$, Liana Jank ${ }^{(1)}$, Cacilda Borges do Valle(1)
} and Ana Lídia Variani Bonato(2)

(1)Embrapa Gado de Corte, Rodovia BR 262, km 4, Caixa Postal 154, CEP 79002-970 Campo Grande, MS, Brazil. E-mail: rosangela@cnpgc.embrapa.br, liana@cnpgc.embrapa.br, cacilda@cnpgc.embrapa.br (2)Embrapa Trigo, Rodovia BR 285, km 174, Caixa Postal 451, CEP 99001-970 Passo Fundo, RS, Brazil. E-mail: analidia@cnpt.embrapa.br

Abstract - The objectives of this work were to estimate the genetic and phenotypic parameters and to predict the genetic and genotypic values of the selection candidates obtained from intraspecific crosses in Panicum maximum as well as the performance of the hybrid progeny of the existing and projected crosses. Seventy-nine intraspecific hybrids obtained from artificial crosses among five apomictic and three sexual autotetraploid individuals were evaluated in a clonal test with two replications and ten plants per plot. Green matter yield, total and leaf dry matter yields and leaf percentage were evaluated in five cuts per year during three years. Genetic parameters were estimated and breeding and genotypic values were predicted using the restricted maximum likelihood/best linear unbiased prediction procedure (REML/BLUP). The dominant genetic variance was estimated by adjusting the effect of full-sib families. Low magnitude individual narrow sense heritabilities $(0.02-0.05)$, individual broad sense heritabilities $(0.14-0.20)$ and repeatability measured on an individual basis $(0.15-0.21)$ were obtained. Dominance effects for all evaluated characteristics indicated that breeding strategies that explore heterosis must be adopted. Less than $5 \%$ increase in the parameter repeatability was obtained for a three-year evaluation period and may be the criterion to determine the maximum number of years of evaluation to be adopted, without compromising gain per cycle of selection. The identification of hybrid candidates for future cultivars and of those that can be incorporated into the breeding program was based on the genotypic and breeding values, respectively. The prediction of the performance of the hybrid progeny, based on the breeding values of the progenitors, permitted the identification of the best crosses and indicated the best parents to use in crosses

Index terms: guineagrass, apomixis, breeding, heritability, repeatability, selection of parents.

\section{Análise biométrica e seleção de progênies tetraplóides de Panicum maximumusando os métodos de modelos mistos}

Resumo - Os objetivos deste trabalho foram estimar parâmetros genéticos e fenotípicos e, predizer os valores genéticos e genotípicos dos candidatos à seleção obtidos de cruzamentos intraespecíficos em Panicum maximum assim como o desempenho da progênie híbrida dos cruzamentos existentes e projetados. Setenta e nove híbridos intraespecíficos, obtidos de cruzamentos artificiais entre cinco indivíduos apomíticos e três sexuais, autotetraplóides, foram avaliados em teste clonal com duas repetições e dez plantas por parcela. Foram avaliados o rendimento de matéria verde, o rendimento de matéria seca total e de folhas além da porcentagem de folhas em cinco cortes anuais durante três anos. Os parâmetros genéticos foram estimados e os valores genéticos e genotípicos foram preditos por meio de procedimento de máxima verossimilhança restrita/melhor predição linear não viciada (REML/BLUP). A variância genética dominante foi estimada ajustando o efeito de família de irmãos germanos. As herdabilidades individuais no sentido restrito $(0,02-0,05)$, no sentido amplo $(0,14-0,20)$ e as repetibilidades individuais $(0,15-0,21)$ foram de baixa magnitude. Efeitos de dominância para todas as características avaliadas indicaram que estratégias de melhoramento que exploram a heterose devem ser adotadas. Evidenciou-se um incremento de menos de 5\% no parâmetro repetibilidade após três anos de avaliações e esse foi o critério para determinar o número máximo de anos de avaliação a ser adotado, sem comprometer o ganho por ciclo de seleção. A seleção de híbridos candidatos a futuras cultivares e daqueles a serem incorporados ao programa de melhoramento foi baseada nos valores genotípicos e genéticos, respectivamente. A predição do desempenho da progênie híbrida, baseada nos valores genéticos dos progenitores, permitiu a identificação dos melhores cruzamentos e indicou os melhores pais a serem usados em cruzamentos.

Termos para indexação: capim colonião, apomixia, melhoramento, herdabilidade, repetibilidade, seleção de genitores. 


\section{Introduction}

The main method of breeding tropical forage grasses consists of the evaluation and selection of natural ecotypes, by exploring the variability found in the accessions introduced from their sites of origin, mainly the African savannas (Hacker \& Jank, 1998; Valle et al., 2001). This procedure is being successfully used for forage grasses, such as Panicum maximum and many Brachiaria species of importance for animal production in Brazil (Pereira et al., 2001). For these species, the selection of natural ecotypes and their use as cultivars is simplified because of the presence of apomixis, i.e. asexual reproduction by means of seeds.

Apomixis presents great advantages in short term breeding by fixing superior genotypes, simplifying breeding procedures and reducing the costs of obtaining seeds (Savidan et al., 1989). In the long term, however, breeding of predominantly apomictic grasses needs crossing procedures. These crosses have multiple functions such as the increase in genetic variability for selection, the exploitation of heterosis and the possibility of a simultaneous gain with selection of many characters of importance in animal production (Pereira et al., 2001)

In P. maximum, the discovery of diploid sexual plants, which later had their chromosome numbers artificially doubled to produce autotetraploids (Combes \& Pernès, 1970), permitted crosses with tetraploid apomictic individuals. Breeding procedures for $P$. maximum based on crosses between sexual and apomictic individuals initially proposed by Smith (1975) and implemented by Savidan et al. (1989), aimed at transferring, by backcrossing, the stoloniferous growth habit characteristic of highly productive individuals. In crosses between sexual and apomictic individuals, Savidan (1983) obtained a proportion of $1: 1$ for mode of reproduction in the offspring, indicating monogenic inheritance.

Pernès et al. (1975) proposed the development of an ideotype which combined the characteristics of sexual and apomictic individuals. This procedure was successfully used in Africa, thus increasing the variation in available sexual genotypes and producing new apomictic germplasm (Savidan et al., 1989).

Artificial crosses with the generation of viable hybrids have been made during the last decade at Embrapa Gado de Corte, Mato Grosso do Sul State, Brazil, in the breeding of $P$. maximum. In this program, Jank et al. (2001) evaluated 79 hybrids obtained from crosses between sexual and apomictic individuals, which were grouped and selected for their performance. The results, however, were not analysed biometrically.

According to Wricke \& Weber (1986) and Gallais (1989b), quantitative genetic models applied to diploids and allopolyploids must be modified before being used on autotetraploids such as $P$. maximum (Warmke, 1951; Combes, 1975; Pernès, 1975), due to the possibility of interaction of more than two alleles at one locus.

In autotetraploids, the genotypic value of an individual, ignoring epistasy, is given, according to Gallais (1989a), as $\mathrm{g}=\mathrm{a}+\mathrm{d}+\mathrm{t}+\mathrm{q}$, in which a is the additive genetic effect; $d$ is the dominant genetic effect or the interaction involving two alleles; $t$ is the genetic effect of the triallelic interactions and $\mathrm{q}$ is the genetic effect of the tetrallelic interactions.

The additive genetic variance and the individual narrow sense heritability cannot be estimated based solely on the evaluation of half-sib progenies or on the progenitors and their offsprings, because in autotetraploids these family relationships also contain fractions of the dominant genetic variance (Gallais, 1989b).

To estimate the four components of variance associated with the effects mentioned above, at least four family relationships are necessary. According to Wricke \& Weber (1986) and Gallais (1989a), the triallelic and tetrallelic effects are of small magnitude and can be neglected. The other effects are important, however. Therefore experimental designs that provide simultaneous half-sib and full-sib progenies should be used to estimate additive and dominance genetic effects.

The selection of candidates for progenitors and hybrids must be based on estimates of the components of variance and the prediction of breeding values obtained by the most accurate means possible, preferably through the use of mixed model (Resende, 2002). With these predictions, it is possible to adopt appropriate selection procedures and outline breeding strategies.

The objectives of this work were to estimate the genetic and phenotypic parameters, to predict the genetic and genotypic values of the selection candidates obtained from intraspecific crosses in P. maximum, and to predict the performance of the hybrid progeny of the existing and the projected crosses.

\section{Material and Methods}

The P. maximum breeding program at the Embrapa Gado de Corte, began in 1982, with the introduction and evaluation of apomictic accessions and sexual plants 
collected by the Institut de Recherche pour le Developpement (IRD) (Jank et al., 1989; Savidan et al., 1989).

Five apomictic accessions (male progenitors), IRD codes T60, T72, T74, T110 and KK10, selected from 156 accessions of the germplasm evaluated agronomically, were used to obtain the intraspecific hybrids (Jank et al., 2001). The three sexual plants (female progenitors), denominated S8, S10 and S12, were produced from diploid sexual plants artificially tetraploidized and selected on their phenotypic evaluation for vigor and foliar characteristics. The crosses made and the number of resulting hybrids per cross are presented on Table 1

A clonal test of the hybrids was planted in November 1995, with two replications, ten plants per plot (two lines of five plants) at a spacing of $0.5 \times 0.5 \mathrm{~m}$. The experiment was established on a Dark-Red Dystrophyc Latosol with the following average composition $(0-20 \mathrm{~cm})$ : $\mathrm{pH} 5.3$; $\mathrm{Al}, \quad 14.3 \mathrm{mmol}_{\mathrm{c}} / \mathrm{dm}^{3} ; \mathrm{Ca}, 12.4 \mathrm{mmol}_{\mathrm{c}} / \mathrm{dm}^{3}$; $\mathrm{Mg}, 4.4 \mathrm{mmol}_{\mathrm{c}} / \mathrm{dm}^{3} ; \mathrm{P}, 1.9 \mathrm{mg} / \mathrm{dm}^{3}$; organic matter, $67.1 \mathrm{~g} / \mathrm{dm}^{3}$ and $43 \%$ of Al saturation. Fertilizer applied at establishment consisted of 1.5 ton/ha of dolomitic lime $800 \mathrm{~kg} / \mathrm{ha}$ of simple superphosphate, $130 \mathrm{~kg} / \mathrm{ha}$ of potassium chlorate and $40 \mathrm{~kg} / \mathrm{ha}$ of FTE BR-16 (a micronutrient mixture) and $100 \mathrm{~kg} / \mathrm{ha}$ of urea after the initial uniform cut.

The evaluation began in December 1996 and was conducted for three years. In the first year, there were four cuts during the rainy season (October 26 and December 3, 1996; March 18 and April 29, 1997) and one cut during the dry season (September 25, 1997). In the second year, there were five cuts during the rainy season (November 6 and December 18, 1997; January 29, March 17 and April 22, 1998) and one cut during the dry season (October 22, 1998), and in the third year, there were three cuts during the rainy season (December 3 1998; January 14 and February 25, 1999) and one cut during the dry season (October 7, 1999).

Table 1. Number of hybrids obtained from intraspecific crosse between three sexual plants (S8, S10 e S12) and five apomictic accessions (T60, T72, T74, T110 and KK10) in Panicum maximum.

\begin{tabular}{crccrcc}
\hline Genotype & T60 & T72 & T74 & T110 & KK10 & Total \\
\hline S8 & $\ldots{ }^{(1)}$ & $\ldots$ & $\ldots$ & $\ldots$ & 14 & 14 \\
S10 & 6 & $\ldots$ & 8 & 17 & $\ldots$ & 31 \\
S12 & 11 & 16 & $\ldots$ & 7 & $\ldots$ & 34 \\
\hline Total & 17 & 16 & 8 & 24 & 14 & 79 \\
\hline${ }^{(1)}$ Crosses were not made. & & & &
\end{tabular}

${ }^{(1)}$ Crosses were not made.
Evaluations were made for green matter yield (GMY), total dry matter yield (TDMY) and leaf dry matter yield (LDMY), evaluated in ton/ha, and leaf percentage (LP). Whole plots were harvested.

Data were analyzed using the restricted maximum likelihood/best linear unbiased prediction procedure (REML/BLUP), with the following univariate model of specific combining ability: $\mathrm{y}=\mathrm{Xb}+\mathrm{Za}_{(12)}+\mathrm{S} \delta_{(12)}+\mathrm{Tp}$ $+\mathrm{e}$, in which $\mathrm{y}$ is the data vector; $\mathrm{b}$ is the fixed effect (combination year - block); $a_{(12)}$ is the additive genetic effect (random); $\delta_{(12)}$ is the dominance effect associated with full-sib families (random); $\mathrm{p}$ is the permanent environmental effect (random) and e is the random error. $\mathrm{X}, \mathrm{Z}, \mathrm{S}$ and $\mathrm{T}$ are incident matrices for $\mathrm{b}, \mathrm{a}_{(12)}, \delta_{(12)}$ and $\mathrm{p}$, respectively.

Data were analyzed with the mixed models methodology, using the program DFREML version $3.0 \beta$ (Meyer, 1998). In this procedure, the additive genetic variance $\left(\sigma_{a}^{2}\right)$ was estimated directly making use of the additive genetic relationship matrix. The dominance variance $\left(\sigma_{d}^{2}\right)$ was estimated by fitting the full-sib family effect $\left(\sigma_{\mathrm{f}}^{2}\right)$ where expectation was $2 / 9\left(\sigma_{\mathrm{d}}^{2}\right)$.

The parameter repeatability $(\rho)$ was estimated by $\rho=\left(\sigma_{\mathrm{f}}^{2}+\sigma_{\mathrm{p}}^{2}+\sigma_{\mathrm{a}}^{2}\right) / \sigma_{\mathrm{Y}}^{2}$, in which $\sigma_{\mathrm{f}}^{2}$ is the genetic variance among full-sib families; $\sigma_{\mathrm{p}}^{2}$ is the permanent environmental variance; $\sigma_{a}$ is the additive genetic variance and $\sigma_{\mathrm{Y}}^{2}$ is the phenotypic variance.

The permanent environmental variance, named general environmental variance by Falconer \& Mackay (1996), refers to the variance that contributes to the between-individual component and arises from permanent or non-localized circumstances.

The predicted genotypic value $(\mathrm{GV})$ of the offspring of the existing crosses was given by $\mathrm{GV}=\mu+1 / 2\left(\hat{\mathrm{a}}_{\mathrm{m}}+\right.$ $\left.\hat{a}_{f}\right)+$ fâm (Resende, 2002) (1), in which $\mu$ is the overall mean; $\hat{a}_{m}$ is the additive genetic effect predicted for the apomictic progenitor and $\hat{a}_{f}$ is the additive genetic effect predicted for the sexual progenitor and fâm is the family effect.

Disregarding the family effect in (1), the performance of the hybrid progeny (PP) was predicted for the existing crosses and for the projected crosses.

The additive genetic values of the progenitor and hybrids were predicted by $\mathrm{BV}=\hat{\mathrm{a}}+\mu$, in which $\mathrm{a}$ is the predicted additive genetic effect.

The genotypic values of the evaluated hybrids were predicted by GVpoffspring $=\hat{a}+$ fâm + pêrm $(3 / 4) \sigma_{d}^{2} / \sigma_{y p}^{2}+\mu$ (Resende, 2002), in which pêrm is the permanent effect; $\sigma_{\mathrm{d}}$ is the dominant genetic variance and $\sigma_{\mathrm{Yp}}^{2}$ is the permanent phenotypic variance. 


\section{Results and Discussion}

The magnitude of the heritability denotes the degree of difficulty of improving a particular character, and indicates the most efficient breeding method to be used. Narrow sense individual heritabilities of low magnitude were found for yield characters in $P$. maximum, estimated for each individual evaluation, for the total annual and for three-year evaluations (Tables 2 and 3 ). These values endorse previous results that characters related to yield in perennial forages are, generally, of low heritability (Gallais, 1992; Casler et al., 1998). Thus more elaborate methods of selection, based on family information, should be used in intra-populational breeding for yield in this species.

The differences in magnitude between estimates of narrow and broad sense heritabilities indicate the presence of dominance effects for all evaluated characters (Table 2). Thus breeding strategies should seek to explore heterosis in P. maximum. The adoption of recurrent reciprocal selection schemes is the mos appropriate breeding and selection strategy for this species (Figure 1). Recombination is only possible in the sexual population, however. Therefore specific combining ability between apomictic and sexua

Table 2. Estimated genetic parameters for green matter yield, total dry matter yield, leaf dry matter yield and leaf percentage, in Panicum maximum for each evaluation cut during three years.

\begin{tabular}{ccccc}
\hline Parameters $^{(1)}$ & $\begin{array}{c}\text { Green } \\
\text { matter }\end{array}$ & $\begin{array}{c}\text { Dry } \\
\text { matter }\end{array}$ & $\begin{array}{c}\text { Leaf } \\
\text { dry matter }\end{array}$ & $\begin{array}{c}\text { Leaf } \\
\text { percentage }\end{array}$ \\
\hline $\mathrm{h}_{\mathrm{a}}^{2}$ & 0.00 & 0.02 & 0.05 & 0.10 \\
$\mathrm{~h}_{\mathrm{g}}^{2}$ & 0.20 & 0.14 & 0.16 & 0.13 \\
$\rho$ & 0.21 & 0.15 & 0.18 & 0.13 \\
$\mu$ & $55.04 \pm 1.75$ & $9.84 \pm 0.21$ & $8.06 \pm 0.18$ & $67.60 \pm 0.41$ \\
\hline
\end{tabular}

${ }^{(1)} \mathrm{h}_{\mathrm{a}}^{2}$ : individual narrow sense heritability; $\mathrm{h}_{\mathrm{g}}^{2}$ : individual broad sens heritability; $\rho$ : repeatability; $\mu$ : overall mean \pm standard deviation

Table 3. Estimated genetic parameters for total dry matter yield and leaf dry matter yield in Panicum maximum, under different number of years of evaluation.

\begin{tabular}{|c|c|c|c|c|c|c|c|c|}
\hline \multirow{2}{*}{$\begin{array}{c}\text { Parame- } \\
\text { ters }^{(1)}\end{array}$} & \multicolumn{3}{|c|}{ Dry matter } & \multicolumn{5}{|c|}{ Leaf dry matter } \\
\hline & Annual & $\begin{array}{l}\text { Two } \\
\text { years }\end{array}$ & $\begin{array}{l}\text { Three } \\
\text { years }\end{array}$ & Annual & $\begin{array}{l}\text { Two } \\
\text { years }\end{array}$ & $\begin{array}{l}\text { Three } \\
\text { years }\end{array}$ & $\begin{array}{l}\text { Four } \\
\text { years }\end{array}$ & $\begin{array}{l}\text { Five } \\
\text { years }\end{array}$ \\
\hline $\mathrm{h}_{\mathrm{a}}^{2}$ & 0.05 & 0.06 & 0.08 & 0.15 & 0.20 & 0.21 & 0.23 & 0.24 \\
\hline$h_{g}^{2}$ & 0.44 & 0.60 & 0.68 & 0.47 & 0.62 & 0.68 & 0.72 & 0.75 \\
\hline$\rho$ & 0.47 & 0.64 & 0.73 & 0.52 & 0.64 & 0.77 & 0.81 & 0.85 \\
\hline
\end{tabular}

${ }^{(1)} \mathrm{h}_{\mathrm{a}}^{2}$ : individual narrow sense heritability; $\mathrm{h}_{\mathrm{g}}^{2}$ : individual broad sense heritability; $\rho$ : repeatability. progenitors should be taken into account when breeding and selecting in the sexual population. This procedure differentiates the present proposal from the ones presented by Pernès et al. (1975) for $P$. maximum and by Valle \& Miles (1992) for Brachiaria spp., i.e., the improvement of the autotetraploid sexual population as a function of the apomictic population. Also, a selection of crosses in each generation is proposed with the objective of increasing the number of individuals in the progeny of the progenitors with best specific combining ability and thus increasing the probability of identifying the best genotypic combination resulting from this cross. These strategies should provide a fast development of improved cultivars, mainly through the exploitation of apomixis in the superior hybrids.

The use of repeated measures is a common and necessary practice in the evaluation of perennial forages, which is of importance in the prediction of breeding, genotypic and phenotypic values, as well as increasing selective efficiency. Repeatability for all characters evaluated in $P$. maximum was low when measured on individual basis (Table 2). Repeatability estimates for the character TDMY were made on one, two and threeyear totals, which were classified in magnitude as moderate to high, respectively (Table 3).

Repeatabilities for the character LDMY were estimated for one, two, three, four and five years. The repeatability based on four-year evaluations was only $5 \%$ higher than that obtained after three years, and increments would have been ever smaller in subsequent years (Table 3). It can be inferred, therefore, that the evaluation for more than three consecutive years will not increase selection efficiency significantly, but will reduce gain per unit of time.

Repeatability estimates for the characters associated to productivity in forages are generally classified as of moderate to high magnitude, as obtained by Casler et al. (1998) in Elymus repens, by Di Renzo et al. (2000) in Eragrostis curvula, by Pereira et al. (1998), Ferreira et al. (1999) and Botrel et al. (2000) in Medicago sativa and by Jahufer \& Gawer (2000) in Trifolium repens, but they vary in number of annual measures to obtain a coefficient of determination or, more appropriately, a higher selective accuracy.

The values of individual broad sense heritabilities and repeatability were very similar for the evaluated characters, indicating that the permanent environmental component was low. This information indicates that a good proximity of the genotypic value of the individuals candidate to clonal selection (apomictic individuals candidate to future cultivar) will be obtained based solely 
on the use of repeatability as the regressor of the phenotypic value.

The order of the individuals for the breeding values differed from the order for the genotypic values, thus implying in selection of different individuals for cloning and for use in a long term breeding program (Table 4).

Different strategies of selection may be outlined considering the mode of reproduction of each hybrid, if by apomixis, or sexual. The apomictic hybrids must be ordered based on their genotypic values, so that short term gain from selection may be obtained. Each selected apomictic hybrid is a cultivar candidate and may be included in subsequent stages of evaluation (Figure 1). The predicted genotypic values shows that for lea dry matter yield, the selection of only one individual (Hybrid 1, Table 4), if apomictic, would lead to a gain from selection of approximately $55 \%$ in relation to the overall mean for that character in the experiment $(\mathrm{m}=8.056 \mathrm{ton} / \mathrm{ha})$. The selection of the $20 \mathrm{mos}$ productive hybrids would result in a gain from selection of $24.4 \%$. Through this, even if only part of these hybrids were apomictic, gain from selection would still be obtained

In autotetraploids, according to Gallais (1989b), the possible presence of tri and tetragenic interactions permits the maximization of specific combining ability through reciprocal recurrent selection, in this case, with three or four progenitors involved. Thus, sexual hybrids (Figure 1) could be selected and included in the breeding program to be crossed with apomictic parents and/or with apomictic hybrids.

The sexual hybrids should be selected based on the additive genetic value. This strategy is indicated because some hybrids presented higher leaf dry matter production than that presented by the progenitor with the highest additive genetic value (T74) (Table 4). From the incorporation of these individuals, a greater strictness must be observed in the genealogical control, considered by the REML method, by means of the genetic relationship matrix, eliminating bias due to the effects of selection (Resende, 2002).

Among the progenitors, the one with the best progeny performance was S10xT74 and with the worst performance was S12xT110 (Table 5). Considering just the predicted values for the performance of the hybrid progeny, it was verified that the best cross was not made. The crosses (S10xKK10) and (S8xT74) presented great potential in the generation of superior progenies and should be implemented.

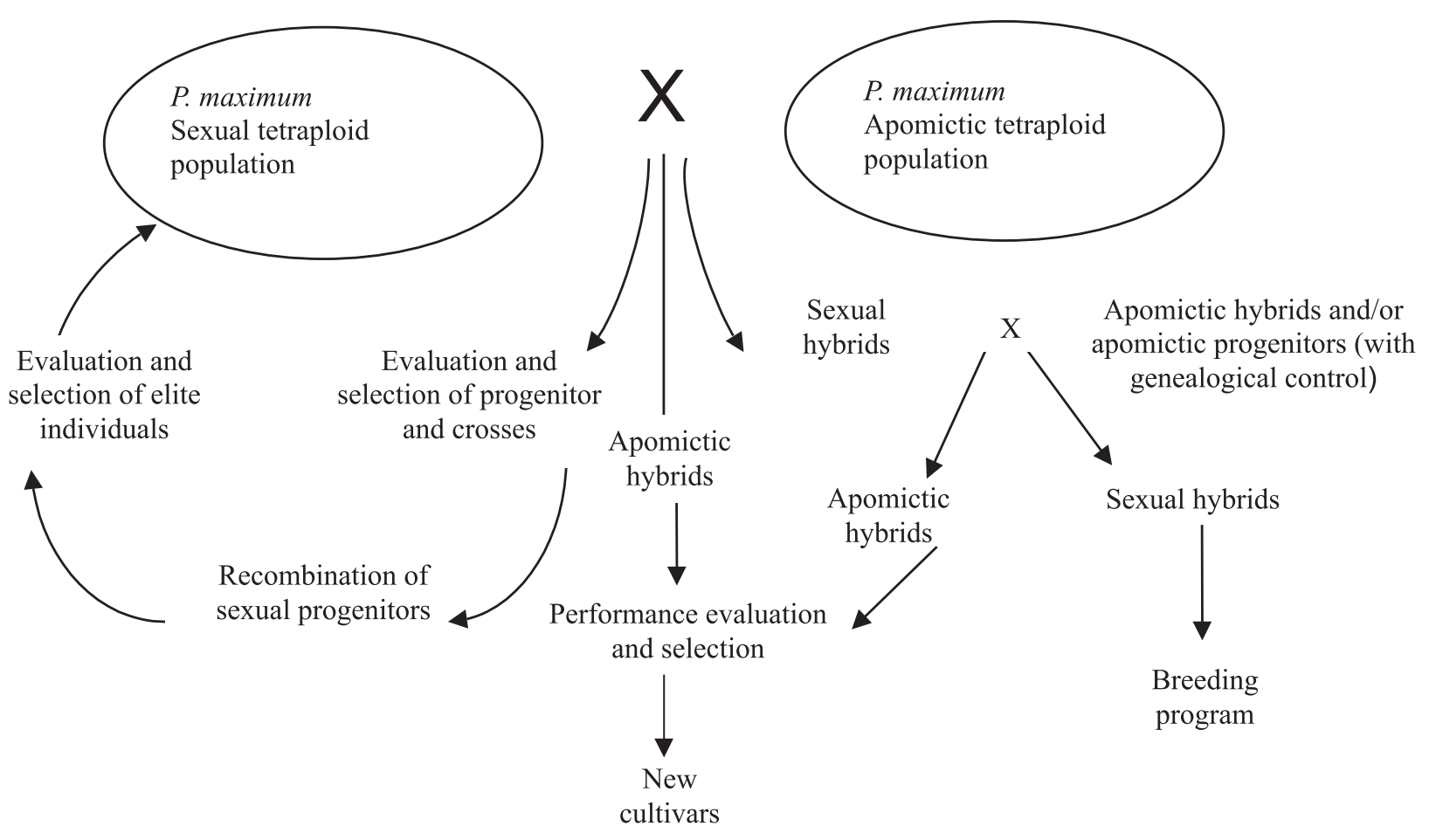

Figure 1. Selection procedures to obtain Panicum maximum cultivars through interpopulational hybridization. 
Table 4. Mode of reproduction, predicted breeding and genotypic values for the twenty best hybrids and the breeding value of the progenitors for the character leaf dry matter yield (ton/ha) in Panicum maximum.

\begin{tabular}{llcc}
\hline Individual & $\begin{array}{c}\text { Reproduction } \\
\text { mode }\end{array}$ & $\begin{array}{c}\text { Breeding } \\
\text { value }\end{array}$ & $\begin{array}{c}\text { Genotypic } \\
\text { value }\end{array}$ \\
\hline T74 & Apomixis & 8.80 & $\ldots$. \\
S10 & Sexual & 8.22 & $\ldots$ \\
KK10 & Apomixis & 8.62 & $\ldots$ \\
S8 & Sexual & 8.62 & $\ldots$ \\
T72 & Apomixis & 7.67 & $\ldots$ \\
T60 & Apomixis & 7.61 & $\ldots$ \\
T110 & Apomixis & 7.65 & $\ldots$ \\
S12 & Sexual & 7.41 & $\ldots$ \\
Hybrid 1 (S10 xT110) & ND ${ }^{(3)}$ & 7.59 & 12.46 \\
Hybrid 2 (S10 x T74) & ND & 9.07 & 11.85 \\
Hybrid 3 (S10 x T110) & Apomixis & 7.60 & 11.43 \\
Hybrid 4 (S10 x T74) & ND & 8.63 & 10.65 \\
Hybrid 5 (S10 x T74) & Apomixis & 8.56 & 10.42 \\
Hybrid 6 (S8 x KK10) & Apomixis & 8.44 & 10.23 \\
Hybrid 7 (S8 x KK10) & Apomixis & 9.08 & 9.98 \\
Hybrid 8 (S10 x T110) & Sexual & 7.42 & 9.92 \\
Hybrid 9 (S10 x T74) & ND & 9.07 & 9.90 \\
Hybrid 10 (S8 x KK10) & ND & 8.69 & 9.76 \\
Hybrid 11 (S8 x KK10) & Apomixis & 9.44 & 9.75 \\
Hybrid 12 (S10 x T110) & Sexual & 7.92 & 9.70 \\
Hybrid 13 (S12 x T60) & ND & 7.69 & 9.39 \\
Hybrid 14 (S10 x T60) & Apomixis & 8.45 & 9.39 \\
Hybrid 15 (S10 x T74) & Fac. Apomixis & 7.83 & 9.37 \\
Hybrid 16 (S8 x KK10) & ND & 8.70 & 9.35 \\
Hybrid 17 (S8 x KK10) & ND & 8.07 & 9.27 \\
Hybrid 18 (S8 X KK10) & ND & 8.52 & 9.24 \\
Hybrid 19 (S8 X KK10) & Sexual & 8.45 & 9.21 \\
Hybrid 20 (S10 X T110) & Apomixis & 8.12 & 9.15 \\
\hline (1) Not predicted. (2)Progenitors between brackets. ${ }^{(3)}$ Not determined.
\end{tabular}

Table 5. Prediction of the performance of the hybrid progeny of the existing and projected crosses and predicted genotypic values of the offsprings of the existing crosses in Panicum maximum for leaf dry matter yield.

\begin{tabular}{|c|c|c|}
\hline Cross & Progeny performance & Genotypic value \\
\hline & \multicolumn{2}{|c|}{ Existing crosses } \\
\hline $\mathrm{S} 10 \times \mathrm{T} 74$ & 8.51 & 9.50 \\
\hline S8 x KK10 & 8.62 & 9.33 \\
\hline $\mathrm{S} 10 \times \mathrm{T} 110$ & 7.94 & 8.49 \\
\hline $\mathrm{S} 10 \times \mathrm{T} 60$ & 7.91 & 7.21 \\
\hline $\mathrm{S} 12 \times \mathrm{T} 72$ & 7.54 & 7.85 \\
\hline $\mathrm{S} 12 \times \mathrm{T} 110$ & 7.53 & 5.51 \\
\hline \multirow[t]{2}{*}{$\mathrm{S} 12 \times \mathrm{T} 60$} & 7.51 & 7.55 \\
\hline & \multicolumn{2}{|c|}{ Projected crosses } \\
\hline S $10 \times \mathrm{KK} 10$ & 8.42 & $\ldots^{(1)}$ \\
\hline $\mathrm{S} 10 \times \mathrm{T} 72$ & 7.95 & $\ldots$ \\
\hline $\mathrm{S} 12 \times \mathrm{T} 74$ & 8.11 & $\ldots$ \\
\hline S12 $\times$ KK 10 & 8.02 & $\cdots$ \\
\hline $\mathrm{S} 8 \times \mathrm{T} 74$ & 8.71 & $\cdots$ \\
\hline S8 x T110 & 8.14 & $\cdots$ \\
\hline S8 $\times$ T72 & 8.15 & ... \\
\hline $\mathrm{S} 8 \times \mathrm{T} 60$ & 8.12 & $\ldots$ \\
\hline
\end{tabular}

Pesq. agropec. bras., Brasília, v.39, n.4, p.335-341, abr. 2004
Based on these results, a strategy to generate superior individuals must include a significant increase in the size of the progeny of these crosses. This improves the probability of obtaining and selecting superior genotypic combinations, and of exploring the superior limit of the specific combining ability through selection of the best possible genotype within the best cross.

This well-founded strategy will promote short-term gains from selection through the production of large numbers of individuals for further stages of evaluation.

\section{Conclusions}

1. Traits related to production in $P$. maximum present narrow sense heritabilities of low magnitude, which are lower than the individual broad sense heritabilities, thus indicating the most adequate breeding strategy for this species.

2. Broad sense heritability and repeatability present similar magnitudes, showing that the permanent environmental effect is not representative and that the use of repeatability as a regressor of the phenotypic value may approximate to the genotypic value of the individual candidates for clonal selection.

3. The genetic and genotypic values of the hybrids and of the progenies of the existing and the projected crosses, can be predicted to obtain short and long term gains from selection, through the use of an univariate model of specific combining ability.

\section{References}

BOTREL, M.A.; FERREIRA, R.P.; CRUZ, C.D.; PEREIRA, A.V.; VIANA, M.C.M.; ROCHA, R.; MIRANDA, M. Estimations of repeatability coefficients for dry matter production in alfalfa cultivars, under different environments. Revista Ceres, v.47, p.651-663, 2000. CASLER, M.D.; GREUB, L.J.; CARLSON, S.K.; COLLINS, M. Genetic variation and selection for shoot and rhizome growth traits in a naturalized quackgrass population. Crop Science, v.38, p.1697$1703,1998$.

COMBES, D. Polymorphisme et modes de reproduction dans la section des Maximae du genre Panicum (Graminées) en Afrique. Paris: ORSTOM, 1975. 99p. (Mémoires, 77).

COMBES, D.; PERNÈS, J. Variations dans les nombres chromosomiques du Panicum maximum Jacq. en relation avec le mode de reproduction. Comptes Rendus de L'Academie des Sciences, v.270, p.782-785, 1970.

DI RENZO, M.A.; IBANEZ, M.A.; BONAMICO, N.C.; POVERENE, N.M. Estimation of repeatability and phenotypic correlations in Eragrostis curvula. Journal of Agricultural Science, v.134, p.207-212, 2000 
FALCONER, D.S.; MACKAY, T.F.C. Introduction to quantitative genetics. 4th ed. Harlow: Longman, 1996. 464p.

FERREIRA, R.P.; BOTREL, M.A.; PEREIRA, A.V.; CRUZ, C.D. Evaluation of lucerne cultivars and estimates of repeatability coefficient of forage traits. Pesquisa Agropecuária Brasileira, v.34 p.995-1002, 1999.

GALLAIS, A. Analysis of variance components of testcrosses progenies in autotetraploid species and consequences for recurren selection with a tester. Theoretical and Applied Genetics, v.83, p.353-359, 1992.

GALLAIS, A. Concepts of varietal value and of test value in autotetraploids: application to genetic advance in population improvement. Genome, v.32, p.420-424, 1989a.

GALLAIS, A. Theorie de la selection en amelioration des plantes. Paris: Masson, 1989b. 588p.

HACKER, B.; JANK, L. Breeding tropical and subtropical grasses. In: CHERNEY, J.H.; CHERNEY, D.J.R. (Ed.). Grass for dairy cattle. Oxon: CABI, 1998. p.49-71.

JAHUFER, M.Z.Z.; GAWER, F.I. Genotypic variation for seed yield components in white clover (Trifolim repens L.). Australian Journal of Agricultural Research, v.51, p.657-663, 2000.

JANK, L.; SAVIDAN, Y.H.; COSTA, J.C.G.; VALLE, C.B. Pasture diversification through selection of new Panicum maximum cultivars in Brazil. In: INTERNATIONAL GRASSLAND CONGRESS, 16. 1989, Nice. Proceedings. Nice: Association Française pour la Production Fourragere, 1989. p.275-276.

JANK, L.; VALLE, C.B.; CARVALHO, J.; CALIXTO, S. Evaluatio of guineagrass (Panicum maximum Jacq) hybrids in Brazil. In INTERNATIONAL GRASSLAND CONGRESS, 19., 2001, São Pedro. Proceedings. FEALQ: Piracicaba, 2001. p.498-499.

MEYER, K. DFREML: version $3.0 \beta$ user notes. Edinburgh: Institute of Animal Genetics of Edinburgh; Animal Genetics and Breeding Unit of the University of New England, 1998. 31p.

PEREIRA, A.V.; FERREIRA, R.P.; CRUZ, C.D.; FREITAS, V.P.; OLIVEIRA, P.T.A. Performance of lucerne cv. Crioula of different origins and repeatability coefficient estimates for forage traits. Revista Brasileira de Zootecnia, v.27, p.686-690, 1998.
PEREIRA, A V. VALLE C.B ; FERREIRA, R.P. MILES, JW. Melhoramento de forrageiras tropicais. In: NASS, L.L.; VALOIS, A.C.C.; MELO, I.S.; VALADARES-INGLIS, M.C. (Ed.). Recursos genéticos e melhoramento: plantas. Rondonópolis: Fundação MT, 2001. p.549-601.

PERNÈS, J. Organization évolutive d'un group agamique: la section des Maximae du genere Panicum (Graminées). Paris: ORSTOM, 1975. 106p. (Mémoires, 75).

PERNÈS, J.; RÉNÉ-CHAUME, R.; RENÉ, J.; SAVIDAN, Y. Schéma d'amélioration génetique des complexes agamiques du type Panicum. Cahiers ORSTOM Biologique, v.10, p.67-75, 1975.

RESENDE, M.D.V. Genética biométrica e estatística no melhoramento de plantas perenes. Brasília: Embrapa-SCT, 2002. 975p.

SAVIDAN, Y.H. Genetics and utilization of apomixis for the improvement of guineagrass (Panicum maximum Jacq.) In: INTERNATIONAL GRASSLAND CONGRESS, 14., 1981, Lexington. Proceedings. Westview: Boulder, 1983. p.182-184.

SAVIDAN, Y.H.; JANK, L.; COSTA, J.C.G.; VALLE, C.B. Breeding Panicum maximum in Brazil - I: genetic resources, modes of reproduction and breeding procedures. Euphytica, v.41, p.107-112, 1989.

SMITH, R.L. Breeding Panicum maximum Jacq. Proceedings of the Soil and Crop Science Society of Florida, v.12, p.624-627, 1975.

VALLE, C.B.; MILES, J.W. Breeding of apomictic species. Apomixis Newsletter, v.5, p.37-47, 1992

VALLE, C.B.; PEREIRA, A.V.; JANK, L. Melhoramento de forrageiras tropicais. In: CONGRESSO BRASILEIRO DE MELHORAMENTO DE PLANTAS, 1, 2001, Goiânia. Anais. Goiânia: Embrapa-CNPAF; Universidade Federal de Goiás; Agência Rural, 2001. 5p. 1 CD-ROM. Seção palestras - melhoramento de forrageiras tropicais.

WARMKE, H.E. Cytotaxonomic investigations of some varieties of Panicum maximum and $P$. purpurascens in Puerto Rico. Agronomy Journal, v.43, p.143-149, 1951.

WRICKE, G.; WEBER, W.E. Quantitative genetics and selection in plant breeding. Berlin: W. de Gruyter, 1986. 406p. 
